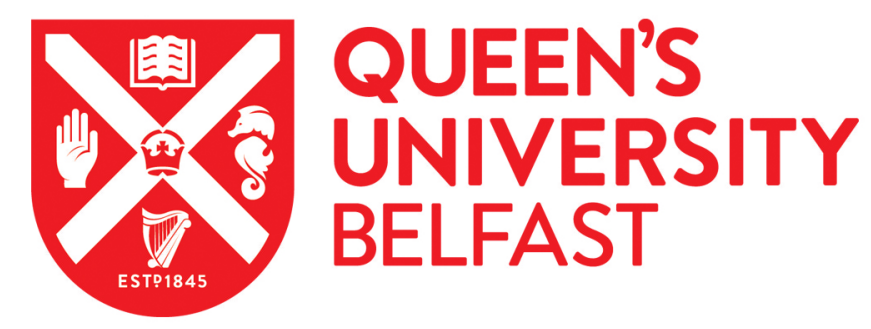

\title{
Familial keratoconus with cataract: linkage to the long arm of chromosome 15 and exclusion of candidate genes
}

\author{
Silvestri, G., Hughes, A., Jackson, J., Dash, D., \& Frazer, D. G. (2003). Familial keratoconus with cataract: \\ linkage to the long arm of chromosome 15 and exclusion of candidate genes. Investigative Ophthalmology and \\ Visual Science, 44(12)(12), 5063-5066. https://doi.org/10.1167/iovs.03-0399
}

\section{Published in:}

Investigative Ophthalmology and Visual Science

\section{Queen's University Belfast - Research Portal:}

Link to publication record in Queen's University Belfast Research Portal

\section{General rights}

Copyright for the publications made accessible via the Queen's University Belfast Research Portal is retained by the author(s) and / or other copyright owners and it is a condition of accessing these publications that users recognise and abide by the legal requirements associated with these rights.

Take down policy

The Research Portal is Queen's institutional repository that provides access to Queen's research output. Every effort has been made to ensure that content in the Research Portal does not infringe any person's rights, or applicable UK laws. If you discover content in the Research Portal that you believe breaches copyright or violates any law, please contact openaccess@qub.ac.uk. 


\title{
Familial Keratoconus with Cataract: Linkage to the Long Arm of Chromosome 15 and Exclusion of Candidate Genes
}

\author{
Anne E. Hughes, ${ }^{1}$ Durga P. Dash, ${ }^{1}$ A. Jonathan Jackson, ${ }^{2}$ David G. Frazer, ${ }^{2}$ \\ and Giuliana Silvestri ${ }^{3}$
}

\begin{abstract}
Purpose. Keratoconus and cataract are common causes of visual morbidity. Both conditions show genetic predisposition. The purpose of this study was to map the disease locus in a large three-generation family affected by combined early-onset autosomal dominant anterior polar cataract and clinically severe keratoconus. Uniquely, in this family both disorders were present and fully penetrant in those affected.
\end{abstract}

Methods. Thirty members of the family were examined clinically on two occasions, at an interval of 5 years, to establish their phenotypes and determine the progression of the disease. Genomic DNA was extracted from blood samples of 16 affected and 14 unaffected individuals, and typed with more than 350 highly polymorphic microsatellite loci in a genome-wide linkage screen. Markers were amplified by PCR with fluorescently labeled primers and sized with an automated DNA analyser before calculation of lod scores. After linkage was established, several positional candidate genes were assessed by PCR-based DNA sequencing.

RESults. The locus for keratoconus with cataract was mapped to a $6.5-\mathrm{Mb}$ region of the long arm of chromosome 15 , at 22.33-24.2 between CYP11A and D15S211. The positional and functional candidate genes CTSH, CRABP1, IREB2, and RASGRF1 were excluded as the cause of keratoconus with cataract in this family.

Concuusions. This is the first report of a family with autosomal dominant inheritance of keratoconus in association with cataract. The causative gene maps to the long arm of chromosome 15 but has not yet been identified. (Invest Ophthalmol Vis Sci. 2003;44:5063-5066) DOI:10.1167/iovs.03-0399

lthough progress had been made in understanding the
molecular mechanisms in many corneal dystrophies, ker-
atoconus remains largely unexplained. It is a noninflammatory,
bilateral, but asymmetrical, corneal stromal dystrophy that
causes central or paracentral thinning and ectasia, and leads to
progressively blurred vision due to distortion and myopic astig-
matism. The incidence of keratoconus is estimated to be 1 in
2000 of the population, ${ }^{1,2}$ with all races being affected. Onset

From the Departments of ${ }^{1}$ Medical Genetics and ${ }^{3}$ Ophthalmology, Queen's University, Belfast, United Kingdom; and the ${ }^{2}$ Department of Ophthalmology, Royal Victoria Hospital, Belfast, United Kingdom.

Supported by grants from The Guide Dogs for the Blind Association and the Northern Ireland HPSS Research and Development Office. Submitted for publication April 22, 2003; revised July 25, 2003; accepted August 7, 2003.

Disclosure: A.E. Hughes, None; D.P. Dash, None; A.J. Jackson, None; D.G. Frazer, None; G. Silvestri, None

The publication costs of this article were defrayed in part by page charge payment. This article must therefore be marked "advertisement" in accordance with 18 U.S.C. $\$ 1734$ solely to indicate this fact

Corresponding author: Anne Hughes, Department of Medical Genetics, Belfast City Hospital, Lisburn Road, Belfast BT9 7AB, UK; a.hughes@qub.ac.uk. of keratoconic refractive errors is usually before the age of 25 years. ${ }^{3}$ Keratoconus is the most common condition for which corneal grafts are undertaken in early and middle age. Despite the availability of early surgical treatment, childhood cataract causes significant visual morbidity and accounts for $10 \%$ to $30 \%$ of legally blind children under the age of 15 years.

Genes play a role in development of both keratoconus and cataract, although genetic predisposition in keratoconus is complex. Autosomal dominant inheritance is indicated in 5\% of clinically significant keratoconus; however, until recently most cases were thought to be sporadic. ${ }^{4,5}$ The advent of corneal topographical mapping and the consequent ability to detect subclinical cases has caused revision of this statistic. Using sophisticated methods such as topography and regression analysis, it is possible to demonstrate that asymptomatic parents and siblings of a patient with a clinically obvious case may be affected at a subclinical level. ${ }^{6,7}$ It is estimated now that $90 \%$ of keratoconus is inherited in an autosomal dominant fashion with reduced expression. Approximately 25\% of childhood cataract is inherited, usually as an autosomal dominant trait. ${ }^{8}$ Autosomal recessive cataract is rare, but is more common in those communities where consanguinity is more prevalent. $\mathrm{X}$-linked cataract is exceedingly rare. Numerous cataract loci have been mapped, and causative mutations have often been identified in genes encoding lens crystallins, ${ }^{9}$ the major soluble proteins in the lens of vertebrate eyes and important for lens clarity. Genetically determined cataracts are a heterogeneous group of disorders and often occur in association with other ophthalmic manifestations, such as microphthalmos, glaucoma, and coloboma.

We report linkage of the first family to be described with autosomal dominantly inherited keratoconus with early developmental cataract.

\section{Methods}

\section{Patients and Clinical Studies}

We identified a large Northern Irish family of three generations (Fig. 1). Thirty members of the family were examined on two occasions at an interval of 5 years to establish the clinical phenotype and document the onset and progression of the disease. The research adhered to the tenets of the Declaration of Helsinki.

\section{Molecular Methods}

A genome-wide search for linkage was undertaken in all available members of the family over the age of 13 years with an affected parent. DNA was extracted from blood samples taken from these individuals and (where possible) from both of their parents. The DNA was typed for more than 350 microsatellite marker loci at intervals of approximately $10 \mathrm{cM}$, using a linkage mapping set (MD10; Applied Biosystems, Inc. $[\mathrm{ABI}]$, Foster City, $\mathrm{CA}$ ) and additional markers that were identified from genomic sequences in regions of interest. PCR products for each panel of the mapping set were pooled before analysis on an DNA sequencer (model 3100; ABI). Alleles were then sized (Genotyper 


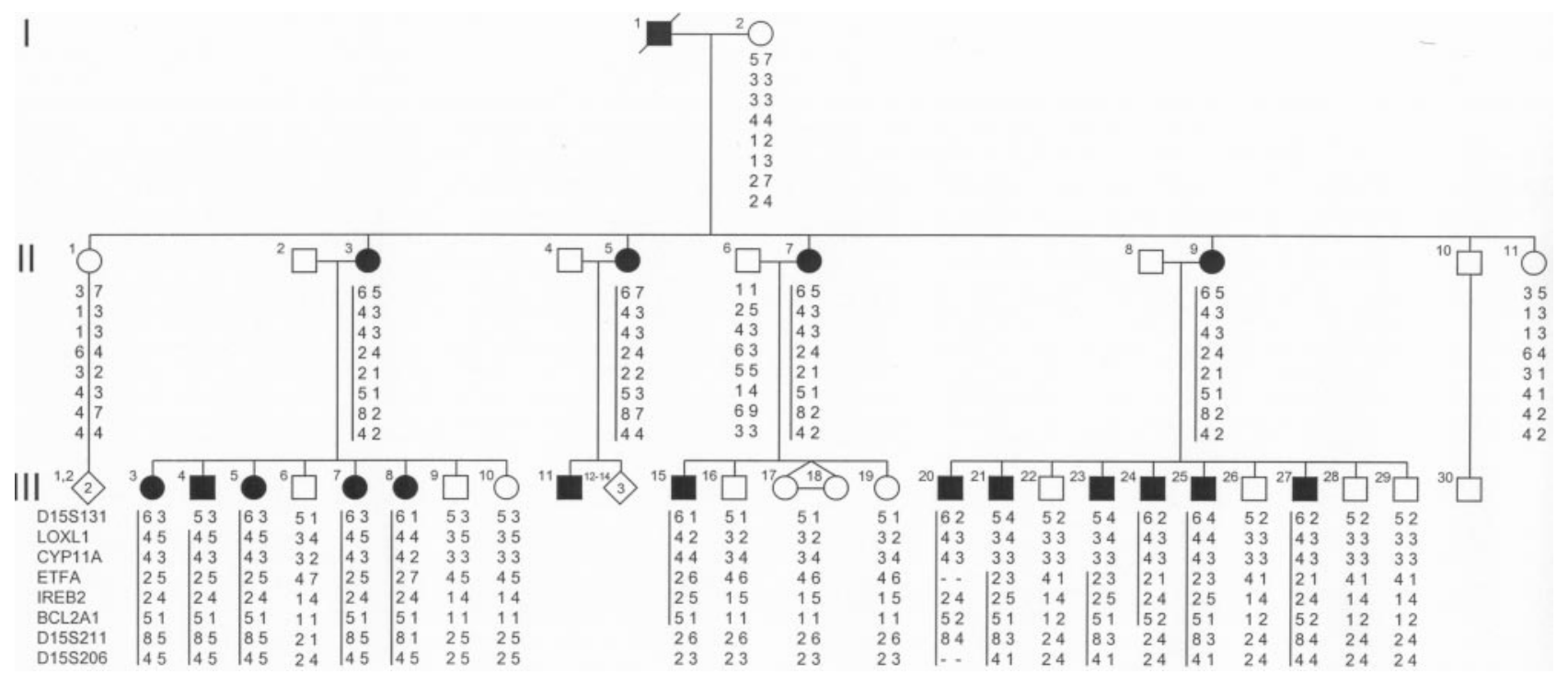

FIGURE 1. Pedigree of the kindred with keratoconus with cataract showing alleles of marker loci (from the top) of D15S131, LOXL1, CYP11A, ETFA, IREB2, BCL2A1, D15S211, and D15S206. The haplotype inherited from the affected parent is shown on the left of each pair; vertical bars represent the inherited portion of the ancestral mutant haplotype in each individual.

software; $\mathrm{ABI}$ ) and scored (C-allele software; available from Shane McKee, Department of Medical Genetics, Queen's University, Belfast, UK). Linkage analysis was performed using FASTLINK ${ }^{10}$ with a fully penetrant disease model (http://softlib.cs.rice.edu; provided in the public domain by Rice University, Houston, TX).

\section{Results}

Examination of the younger individuals was informative and indicated that onset of progressive astigmatism predated onset of lens opacities by 1 to 2 years. Astigmatism manifested around the age of 8 years, and although there was some intrafamilial variation, cones were generally detectable around the age of 9 to 12 years. Individuals who demonstrated neither progressive astigmatism nor lens opacities by the age of 13 appeared to remain unaffected. Corrective surgery was usually necessary in early adulthood for both keratoconus and cataract.

A cluster of panel markers on chromosome 15 showed evidence of linkage, with a maximum 2-point lod score of 3.99 at $\theta=0.11$ with $D 15 S 131$. Further microsatellite markers between $D 15 S 131$ and D15S205 were typed, in addition to new (CA)n markers close to or within LOXL1, CYP11A, ETFA, IREB2, and BCL2A1 (which lie between D15S131 and $D 15 S 211)$. There was evidence of recombination at CYP11A, D15S211 and D15S206, but not at ETFA, IREB2, or BCL2A1 (Table 1; Fig. 1). A haplotype for the latter group of markers could be tracked through all affected but no unaffected mem- bers of the family. III21 and III23 were recombinant at CYP11A, LOXL1, and D15S131 and more proximal markers. III 15 and III24 were recombinant at D15S211,D15S206, and more distal markers. The maximum 2-point lod score of 8.13 was found at IREB2. The causative gene therefore maps within the interval of $6.5 \mathrm{Mb}$ flanked by CYP11A and D15S211 (Fig. 2).

Four positional candidate genes for keratoconus with cataract were screened. All 12 exons of the cathepsin $\mathrm{H}$ gene $(C T S H)$, four exons of the cellular retinoic acid binding protein 1 gene (CRABP1), 22 exons of the iron-responsive element binding protein 2 gene (IREB2), and 26 exons responsible for the two alternative transcripts of the Ras guanine nucleotide releasing factor gene (RASGRF1) were assessed for mutations by PCR-based sequencing with dye terminator chemistry (Big Dye; $\mathrm{ABI}$ ) on the DNA sequencer. No causative mutation was detected in any of these genes. Several single nucleotide polymorphisms were identified, but those that segregated with the affected haplotype through our family were also found in a panel of normal control DNA from unaffected individuals.

\section{Discussion}

The disease gene region is exceedingly gene rich, containing approximately 95 known or predicted genes, none of which is a known cataract gene. There are, nevertheless, several interesting candidate genes for keratoconus and cataract, including

TABLE 1. Two-Point Lod Scores for Keratoconus with Cataract with Markers on Chromosome 15

\begin{tabular}{|c|c|c|c|c|c|c|}
\hline \multirow[b]{2}{*}{ Marker } & \multicolumn{5}{|c|}{ Lod Score at $\theta$} & \multirow[b]{2}{*}{ Maximum Lod } \\
\hline & 0.00 & 0.01 & 0.05 & 0.10 & 0.20 & \\
\hline$D 15 S 131$ & $-\infty$ & 2.02 & 3.67 & 3.98 & 3.61 & 3.99 at $\theta=0.11$ \\
\hline LOXL1 & 6.62 & 6.52 & 6.11 & 5.57 & 4.39 & 6.62 at $\theta=0$ \\
\hline CYP11A & $-\infty$ & 3.11 & 4.10 & 4.16 & 3.59 & 4.19 at $\theta=0.08$ \\
\hline ETFA & 7.83 & 7.71 & 7.22 & 6.59 & 5.21 & 7.83 at $\theta=0$ \\
\hline IREB2 & 8.13 & 8.00 & 7.50 & 6.85 & 5.41 & 8.13 at $\theta=0$ \\
\hline$B C L 2 A 1$ & 7.73 & 7.61 & 7.11 & 6.46 & 5.03 & 7.73 at $\theta=0$ \\
\hline$D 15 S 211$ & $-\infty$ & 4.01 & 4.95 & 4.94 & 4.21 & 5.00 at $\theta=0.07$ \\
\hline D15S206 & $-\infty$ & 1.74 & 2.83 & 3.03 & 2.73 & 3.03 at $\theta=0.10$ \\
\hline
\end{tabular}




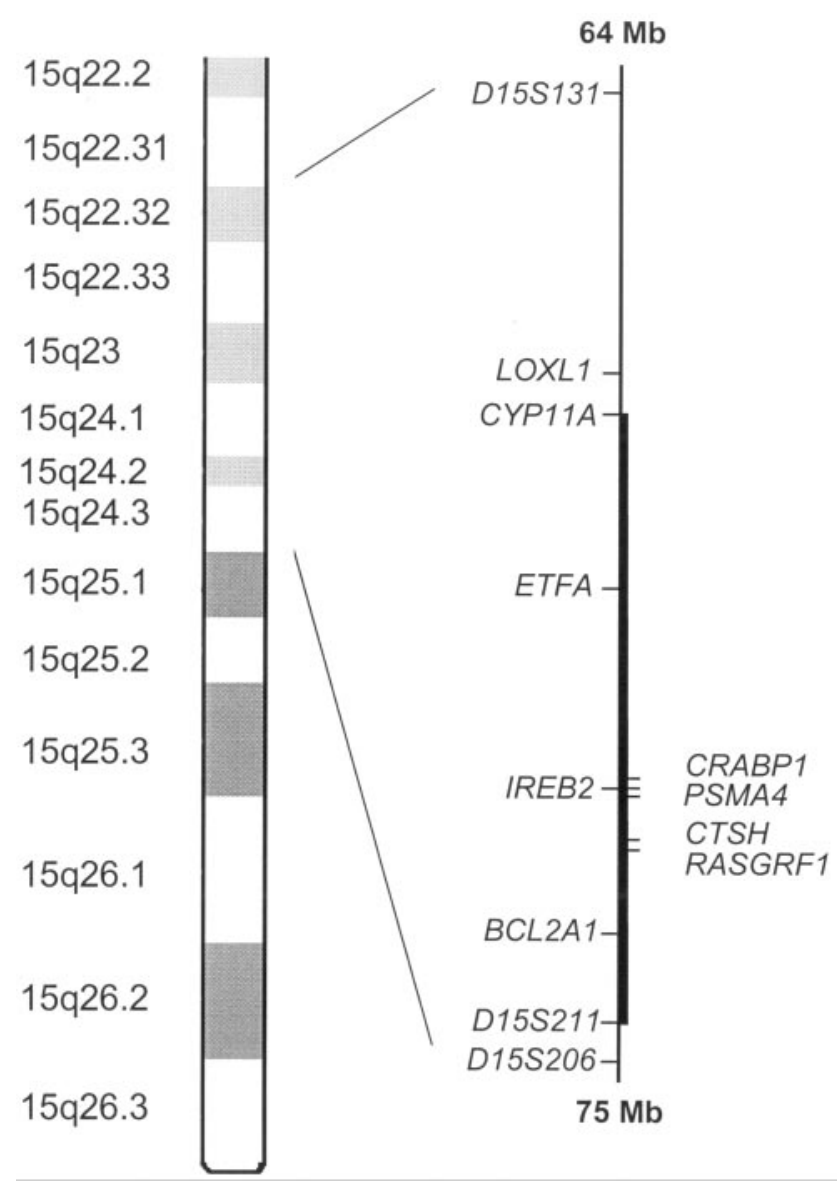

FigURE 2. Map of the linked region of the long arm of chromosome 15 showing markers and genes of interest located between 64 and 75 $\mathrm{Mb}$. Heavy vertical line: critical region of the locus for keratoconus with cataract. Left: linkage markers used in the study; right: candidate genes.

the four genes in which mutations were not found. Cathepsin $\mathrm{H}$ is a cysteine-dependent intracellular protease that is responsible for intracellular protein degradation and turnover. The CTSH gene is widely expressed, including in the lens and other elements of the eye. CRABP1 is also highly expressed in the eye. Its product is one of a family of six vitamin A-binding proteins (two others of which are found only in visual tissue) and is thought to be involved in retinoic acid-mediated differentiation and proliferation processes. Patients with mutations affecting the iron-response element (IRE) in the $5^{\prime}$ untranslated region of the ferritin light chain gene experience development of early onset cataracts. IREB 2 encodes a protein that binds to this motif. ${ }^{11}$ The RASGRF1 gene product shares homology with the guanine nucleotide exchange activator son-of-sevenless in Drosophila melanogaster, which is involved in the sevenless signaling pathway in developing photoreceptors. It also shares similarity with mouse son-of-sevenless (Sos 1), mutations of which dominantly enhance the weak allele of $E g f r$ causing distinctive eye defects including lens opacity and eye dysmorphology. ${ }^{12}$

Three closely related members of the ADAMTS family map within our critical region and are excellent candidates, being expected to play important roles in tissue architecture and degradation. These genes encode disintegrin metalloproteinases with thrombospondin motifs and are involved in proteolysis of the extracellular matrix. DKFZP434H2O4 and $A D A M T S 7$ are supported by expressed sequence tag (EST) data on the National Center for Biotechnology Information chromosome 15 sequence map (build 31). Both show widespread expression in many tissues, but are not prominent in the eye. Screening of this group of genes is not yet complete, due to difficulties arising from the extremely close homology in some exonic and intronic regions.

Clues for prioritizing the candidate genes for future investigation may come from other studies. EDICT syndrome is a recently described form of anterior dysgenesis involving endothelial dystrophy, iris hypoplasia, congenital cataract, and stromal thinning. ${ }^{13}$ One patient in the reported EDICT-affected family had anterior polar cataract. This syndrome has been tentatively linked to a large $26-\mathrm{Mb}$ region on chromosome 15 at q22.1-q25.3 with a lod score of 2.7. This encompasses the region we describe. With some features in common, it is possible that keratoconus with cataract and EDICT syndrome are allelic.

A locus for familial keratoconus has been mapped previously to chromosome 16 at q22.3-q23.1 by a genome-wide linkage study in a group of small Finnish families, ${ }^{14}$ with a maximum parametric multipoint lod score of 4.10. Comparison of the genes within the critical regions identified on chromosomes 15 and 16 highlights candidate genes for our keratoconus and cataract locus. Each interval contains a member of the $A D A M T S$ family and also a gene encoding a proteasome core subunit. ADAMTS7 and ADAMTS18 are closely related, with both having disintegrin and metalloprotease activity. The proteasome is a multicatalytic proteinase complex which cleaves peptides in an ATP/ubiquitin-dependent process in a nonlysosomal pathway. PSMA4 encodes an $\alpha$ subunit of the $20 S$ core, whereas the $P S M D 7$ product is a non-ATPase subunit 7 of the $19 \mathrm{~S}$ regulator. The ubiquitin-proteasome pathway has been implicated in corneal stromal cell repair. ${ }^{15}$ The mutant gene in an inbred line of spontaneously keratoconic mice has been linked to the major histocompatibility complex (MHC) region, ${ }^{16}$ where related immunoproteasome genes are located. There is evidence to suggest that immunoproteasomes may be involved in lens differentiation, ${ }^{17}$ in addition to their role in the processing of class I MHC peptides. There is therefore compelling support for proteasome genes influencing keratoconus and cataract.

Further work is necessary to identify the gene that causes keratoconus and cataract in the family presented in our study. Although keratoconus is likely to be a multifactorial disorder with large phenotypic diversity, there is growing evidence for the importance of genetic factors in its etiology. Despite recent progress in resolving the genetic basis of many of the rare inherited corneal dystrophies ${ }^{18}$ (e.g., lattice, macular, Meesman, Reis-Buckler, and Schnyder), our understanding of the most common dystrophy, keratoconus, remains poor. It is to be hoped that study of the molecular basis of the severe keratoconus phenotype in the family in our study will shed light on the pathogenesis of keratoconus in general and that it will ultimately underpin the development of rational treatment strategies.

\section{References}

1. Pouliquen Y. Doyne lecture: keratoconus. Eye. 1987;1:1-14.

2. Rabinowitz YS. Keratoconus. Surv Opbthalmol. 1998;42:297-319.

3. Ihalainen A. Clinical and epidemiological features of keratoconus genetic and external factors in the pathogenesis of the disease. Acta Opbthalmol Suppl. 1986;178:1-64.

4. Rabinowitz YS, Maumenee IH, Lundergan MK, et al. Molecular genetic analysis in autosomal dominant keratoconus. Cornea. 1992;11:302-308.

5. Edwards M, McGhee CN, Dean S. The genetics of keratoconus. Clin Exp Opbthalmol. 2001;29:345-351. 
6. Gonzalez V, McDonnell PJ. Computer-assisted corneal topography in parents of patients with keratoconus. Arch Ophthalmol. 1992; 110:1413-1414.

7. Morrow GL, Stein RM, Racine JS, Siegel-Bartelt J. Computerized videokeratography of keratoconus kindreds. Can J Ophthalmol. 1997;32:233-243.

8. Francois J. Genetics of cataract. Ophthalmologica. 1982;184:6171.

9. Bloemendal H, de Jong WW. Lens proteins and their genes. Prog Nucleic Acids Res Mol Biol. 1991;41:259-281.

10. Schaffer AA. Faster linkage analysis computations for pedigrees with loops or unused alleles. Hum Hered. 1996;46:226-235.

11. Girelli D, Bozzini C, Zecchina G, et al. Clinical, biochemical and molecular findings in a series of families with hereditary hyperferritinaemia-cataract syndrome. Br J Haematol. 2001;115:334-340.

12. Wang DZ, Hammond VE, Abud HE, Bertoncello I, McAvoy JW, Bowtell DD. Mutation in Sos1 dominantly enhances a weak allele of the EGFR, demonstrating a requirement for Sos1 in EGFR signaling and development. Genes Dev. 1997;11:309-320.
13. Jun AS, Broman KW, Do DV, Akpek EK, Stark WJ, Gottsch JD. Endothelial dystrophy, iris hypoplasia, congenital cataract, and stromal thinning (edict) syndrome maps to chromosome 15q22.1q25.3. Am J Opbthalmol. 2002;134:172-176.

14. Tyynismaa H, Sistonen P, Tuupanen S, et al. A locus for autosomal dominant keratoconus: linkage to 16q22.3-q23.1 in Finnish families. Invest Ophthalmol Vis Sci. 2002;43:3160-3164.

15. Stramer BM, Cook JR, Fini ME, Taylor A, Obin M. Induction of the ubiquitin-proteasome pathway during the keratocyte transition to the repair fibroblast phenotype. Invest Opbthalmol Vis Sci. 2001; 42:1698-1706

16. Tachibana M, Adachi W, Kinoshita S, et al. Androgen-dependent hereditary mouse keratoconus: linkage to an MHC region. Invest Opbthalmol Vis Sci. 2002;43:51-57.

17. Singh S, Awasthi N, Egwuagu CE, Wagner BJ. Immunoproteasome expression in a nonimmune tissue, the ocular lens. Arch Biochem Biophys. 2002;405:147-153.

18. Klintworth GK. Advances in the molecular genetics of corneal dystrophies. Am J Ophthalmol. 1999;128:747-754. 